\title{
加熱によるダイコンの軟化およびペクチンの分解 に関する速度論的解析
}

\author{
岡崎 尚* ・前重静彦 ${ }^{* *} \cdot$ 鈴木寛一***
}

\author{
Kinetic Studies on Softening of Japanese Radish and $\beta$-Elimination \\ of Citrus Pectin during Thermal Processes
}

\author{
Takashi OKazaki ${ }^{*}$, Shizuhiko MAESHIGE ${ }^{* *}$ and Kanichi SUzUKI ${ }^{* * *}$ \\ * Hiroshima Prefectural Food Technological Research Center, 12-70, \\ Hijiyamahonmachi, Minami-ku, Hiroshima-shi, Hiroshima 732 \\ *** Department of Applied Biological Science. Hiroshima University, \\ 1-4-4, Kagamiyama, Higashihiroshima-shi Hiroshima 739
}

In order to clarify thermal softening mechanism of vegetables, the softening rate of vegetable during a thermal process was investigated, comparing with the kinetics for $\beta$-elimination of pectin. A Japanese radish and a citrus pectin were used as samples. The cylindrical samples $(7 \mathrm{~mm} \phi \times 30 \mathrm{~mm}$ in length) were cooked in water in a temperature range from $90^{\circ} \mathrm{C}$ to $110^{\circ} \mathrm{C}$ using a pressure-vessel. The softening behavior obeyed a first order equation. The softening rate constants and the activation energy were $0.17 \times 10^{-3} \mathrm{~s}^{-1} \sim 2.30 \times 10^{-3} \mathrm{~s}^{-1}$ and $146 \mathrm{~kJ} \cdot \mathrm{mol}^{-1}$ from $90^{\circ} \mathrm{C}$ to $110^{\circ} \mathrm{C}$, respectively. The pectin solution $(0.5 \%$ in $\mathrm{M} / 10$ phosphate buffer, $\mathrm{pH} 6.5$ ), which was sealed in a glass tube, was heated in the same temperature range as the Japanese radish. The $\beta$-elimination rate of the pectin was also analyzed by using a first order equation. The rate constants of $\beta$-elimination and the activation energy were $0.33 \times 10^{-4} \mathrm{~s}^{-1} \sim 3.73 \times 10^{-4} \mathrm{~s}^{-1}$ and $143 \mathrm{~kJ} \cdot \mathrm{mol}^{-1}$, respectively. Though the rate constants for softening of Japanese radish were approximately 10 times larger than those for $\beta$-elimination of the pectin, both activation energies were almost the same values. This result suggests that the softening mechanism of Japanese radish might be closely related with the $\beta$-elimination of the pectic substance in the radish.

(Received Apr. 14, 1997 ; Accepted Jun. 11, 1997)

野菜類の加熱による乾化現象は, 調理学的な観点から あ, 食品工業の立場からす, 重要な現象であり, 多くの 報告1) -4) がある. しかしながら，加熱による野菜類の軟 化を野菜の組織および組織内の成分との関係で, 明確に した報告は比較的少ない.

淵上 ${ }^{3) 4)}$ は，加熱によって野菜類が軟化するのは，野 菜中のペクチン質がトランスエリミネーションによって 分解し, 煮汁中に溶出することによって細胞間の結合力 が失われることが主な原因であるとした。一方，ペクチ
ン溶液を用いたモデル実験では，ペクチン質は $\mathrm{pH} 5$ 以 上で加熱処理をするときトランスエリミネーションに

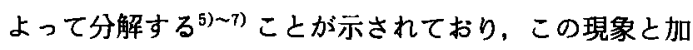
熱による野菜類の軟化現象との関連性が示されている. しかしながら，野菜類の軟化とぺクチン質の分解を関連 させた報告4) は少ない。

そこで，本研究では，加熱によるダイコンの軟化現象 を速度論的に検討し，トランスエリミネーションによる ペクチンの分解速度との関連から，ダイコンの軟化現象

\footnotetext{
"広島県立食品工業技術センター（夏732 広島市南区比治山本町 12-70）

** 元広島県立食品工業技術センター

*** 広島大学生物生産学部（干739 東広島市西条町鏡山 1 丁目 4-4）
} 
を考察した。

\section{実 験 方 法}

\section{1. 実験材料}

(1) ダイコン

ダイコンは, 広島県内で収椣された平均重量 $950 \mathrm{~g} /$ 本，長さ $370 \mathrm{~mm}$ のものを用いた．中央付近を厚さ 30 $\mathrm{mm}$ の輪切りにし，中心部を除く柔組織をコルクボー ラーで円柱状（直径 $7 \mathrm{~mm}$, 長さ $30 \mathrm{~mm}$ ）にくり抜き,

この試料を加熱好理に用いた．各処理温度における測定 は, 1 本のダイコンから得た約 20 個の試料で行い, 各処 理温度について 2，3 回湘定を繰り返した。

\section{(2) ペクチン}

実験に用いたぺクチンは，柑檑由来のペクチン（関東 化学(株)製）を次のように精製して用いた。 ペクチンを 蒸留水で溶加して $1 \%$ ペクチン溶液を調製し，等量の工 タノールを加えた．生じたペクチンの沈殿を徐々にエ夕 ノール濃度を高めながら洗浄を繰り返し，最後に $100 \%$ エタノールで洗鿇後ジェチルェーテルで洗浄して室温で 風乾した。この精製ペクチンを $\mathrm{M} / 10$ リン酸緩衝液 $(\mathrm{pH}$ 6.5）に溶かして $0.5 \%(\mathrm{w} / \mathrm{v})$ ペクチン溶液を調製した。 この溶液を加熱処理に用いた.

\section{2. 試料の加熱}

ダイコンの加熱処理を行う場合には，まず円柱状に整 形した試料を加熱于ェープ'10)（内径 $8 \mathrm{~mm}$ ，外径 12 $\mathrm{mm}$, 長さ $180 \mathrm{~mm}$ ) に挿入し, 蒸留水および水の膨脹圧 を防ぐために若干の空気を入れて密封した. ペクチン溶 液の加熱処理を行う場合には， $0.5 \%$ ペクチン溶液 $2 \mathrm{ml}$ を一方を封じたガラス管（内径 $5 \mathrm{~mm}$, 外径 $7 \mathrm{~mm}$, 長さ $100 \mathrm{~mm}$ ) に注入して溶封した. 次いで，ダイコンを入れ た加熱チューブまたはぺクチン溶液を封入したガラス管 を $25^{\circ} \mathrm{C}$ の恒温槽に 5 分間保った後, $90^{\circ} \mathrm{C} \sim 110^{\circ} \mathrm{C} \pm 0.1^{\circ} \mathrm{C}$ の加熱槽（太陽科学工業(株)製，T-100）に浸清した. 加 熱チューブの浸漬によって加熱槽の温度は約 $0.5^{\circ} \mathrm{C}$ 低下 したが, 約 30 秒後に回復した. 加熱処理後, $25^{\circ} \mathrm{C}$ の水槽 で 5 分間冷却した。なお，加熱槽の熱媒体には $6 \mathrm{~L}$ の水 溶性オイル（(株)キング製作所製)を使用した。

3. 測 定

(1) ダイコンの硬さ

加熱処理した円柱状の試料を長さ $5 \mathrm{~mm}$ に切断し，レ オメー夕（不動工業(株), NRM-2010 J-CW）の試料台 に置き, 平板状プランジャー $(20 \mathrm{~mm} \phi)$ で切断面側から 速度 $120 \mathrm{~mm} / \mathrm{min}$ で押しつふしたときの最大破断応力 （N）を硬さとし，4回測定して得た值の平均值で示し
た.

(2) 4，5-不飽和ガラクツロン

ペクチンは中性またはアルカリ性の水溶液中で加熱す ると,トランスエリミネーション ( $\beta$-脱離と略す) を起 こして低分子化し，4,5-不飽和ガラクッロン酸を生じ る5)。この不飽和ガラクッロン酸を岡本らの方法 ${ }^{(1)} に$ 従って，チオバルビッール酸反応によって湘定した.す なわち、加熱処理したペクチン溶液 $0.4 \mathrm{ml}$ に $0.5 \mathrm{~m} l$ の $0.025 \mathrm{~N}$ 過ヨウ素酸ナトリウム $(0.125 \mathrm{~N}$ 硫酸溶液) を加 えて $80^{\circ} \mathrm{C}$ で 15 分間加熱した. さらに, $1 \mathrm{ml}$ の $2 \%$ 垔七 酸ナトリウム（0.5 N 塩酸溶液）を加えて 2 分後に $4 \mathrm{ml}$ の $0.3 \%$ チオバルビッール酸溶液を加え, $100^{\circ} \mathrm{C}$ で 10 分 間加熱した. 水冷後, $1 \mathrm{~cm}$ セル中で $548 \mathrm{~nm}$ の吸光度を 湘定した。

(3) エステル化度

柑滒ペクチンのガラクッロン酸の定量は, カルバソー 儿硫酸法 ${ }^{8)}$ で行った. ペクチンに結合しているメタノー ルの定量は, 塩田 ${ }^{9}$ らの方法を次のように改変して行っ た.すなわち、約 $0.1 \%$ のペクチン溶液 $0.8 \mathrm{~m} l$ を小型試 験管（スクリューキャップ付）にとり，内部標準として $1000 \mathrm{ppm}$ の-プロパノールを含む $0.25 \mathrm{~N}$ の水酸化ナ トリゥム $0.2 \mathrm{~m} l$ を加えて室温で約 30 分間けん化した. 経時後, $0.2 \mathrm{M}$ 硫酸銅を含む $0.25 \mathrm{~N}$ の硫酸 $0.2 \mathrm{ml}$ を加え て混合し，遠心分離後上澄の $0.4 \mu l$ をガスクロマトグラ フ（島津 GC-5 A，FID）に注入してメタノールを定量し た. ガスクロマトグラフィーは, $3 \times 1000 \mathrm{~mm}$ のガラス カラムに Porapak QS (80〜100 mesh) を充填し, カラ 厶温度 $115^{\circ} \mathrm{C}$, 試料導入部温度 $135^{\circ} \mathrm{C}$ で行った. キャリ アガスには，窑素ガスを用い，流量 $60 \mathrm{ml} / \mathrm{min}$ とした. エステル化度はウロン酸含量に対するメタノールのモル 比（\%）で算出した。

(4) 試料の温度

ダイコンを試料とした場合, 加熱チューブ内の試料の 中心部に位置するようにシース熱電対 (1.5 mm を挿入し、デジタルデータレコータ（三洋電機(株)， DDR) で 2 秒毎に温度変化を記録した。ペクチン溶液の 場合, シース熱電対 $(0.5 \mathrm{~mm} \phi, \mathrm{CA})$ をガラス管の中心 部に固定し, 試料溶液の温度を 2 秒毎に測定した. なお， 加熱チューブまたはガラス管から出ているシース熱電対 の保護管部分は, 直径 $6 \mathrm{~mm}$ のシリコンチューブで顠っ て外からの熱伝導を防止した。

\section{4. 修正加熱時間の計算}

試料の測定加熱時間は，一定の加熱温度で処理した時 間に加えて昇温時間を含むため，みかけの加熱時間とな 
る.したがって、等温過程を仮定した速度論的な解析を 行うためには, 非等温の加熱期間に進行したダイコンの 軟化またはペクチンの分解が, 一定の処理温度で進行し たとみなした相当時間を用いて加熱時間を修正する必要 がある，加熱によるダイコンの軟化およびペクチンの分 解が一次の速度式に従うあのと仮定するとき，加熱時間 の修正は，前報 ${ }^{12)}$ で示した方法で計算することができ る. 本研究では, 測定加熱時間の代わりに, この修正加 熱時間を用いた。

なお,タイコンの場合には $90^{\circ} \mathrm{C}$ 以上で, ペクチン溶液 の場合には $100^{\circ} \mathrm{C}$ 以上の加熱処理において修正加熱時間 を用いた．その加熱温度未満では， みかけの加熱時間と 修正加熱時間との差はわずかな值であった。

\section{実験結果およひ考察}

\section{1. 加熱によるダイコンの硬さの変化}

代表的なダイコンの硬さの変化を $90^{\circ} \mathrm{C} \sim 110^{\circ} \mathrm{C}$ の範囲 で Fig. 1 に示した. 各温度で処理した場合, いずれの温 度下であ加熱初期に末加熱のものよりも約 $20 \%$ ほど硬 さが增大したのち，硬さが隇少した，硬さの隇少度合い は, 処理温度が高くなるほど大きくなった。

加熱初期にダイコンなどの野菜類が一旦硬くなる現象 は，これまでにも報告2) 10116)されているが，本結果であ 同様の現象が認められた。特に, $100^{\circ} \mathrm{C}$ 以上の高温域の 加熱処理においても硬くなっていた。

加熱によるタイコンの硬さの減少過程を“軟化”とし， 軟化率 $\mathrm{X}_{\mathrm{d}}(-)$ を式(1)で表した。

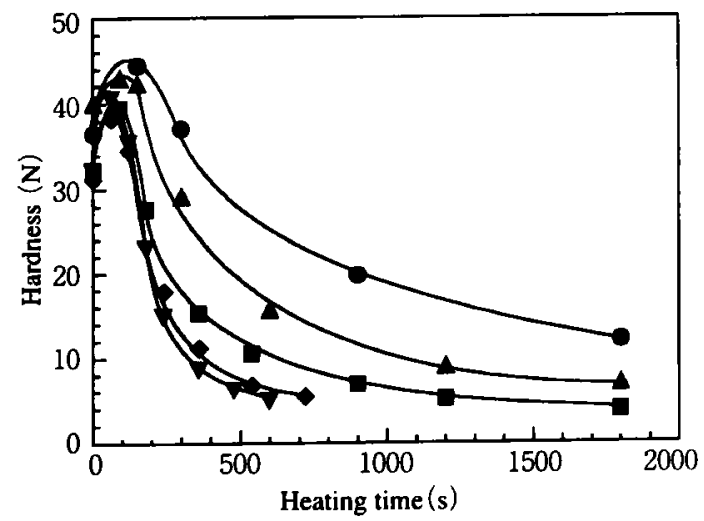

Fig. 1 Changes in hardness of Japanese radish at various temperatures

Heating temperature $\left({ }^{\circ} \mathrm{C}\right):-90 ; \boldsymbol{\Lambda}, 95 ; \boldsymbol{\square}$, $100 ; .105 ; \nabla, 110$.

$$
\mathrm{X}_{\mathrm{d}}=\left(\mathrm{H}_{0}-\mathrm{H}\right) /\left(\mathrm{H}_{0}-\mathrm{H}_{\mathrm{e}}\right)
$$

ここで, $\mathrm{H}_{0}$ は硬さの初期値, $\mathrm{H}_{\mathrm{e}}$ は硬さの平衡値, $\mathrm{H}$ は加 熱時間 $\mathrm{t}$ における硬さである. ダイコンは加熱初期に末 加熱のものより平均 $20 \%$ 硬化したので，その硬化によ る軟化の遅れを補正するために未加熱試料の硬さを 1.2 倍した值を初期值とした，軟化の平衡值は，各処理温度 において，軟化の進行がほとんど止まったときの硬さの

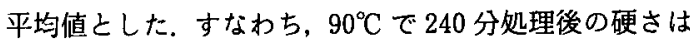
$3.01 \mathrm{~N}$, 同じく $95^{\circ} \mathrm{C}$ で 120 分後 $2.52 \mathrm{~N}, 100^{\circ} \mathrm{C}$ で 60 分後 $2.30 \mathrm{~N}, 105^{\circ} \mathrm{C}$ で 30 分後 $2.48 \mathrm{~N}, 110^{\circ} \mathrm{C}$ で 20 分後 $2.75 \mathrm{~N}$ となり,これらの平均値 $2.61 \mathrm{~N}$ を軟化の平衡値とした.

加熱によるダイコンの軟化を一次の速度式で近似して 解析している ${ }^{2116)}$ 場合も多く，本報告でもダイコンの軟 化は一次の速度式(2)で近似できるすのと仮定し，次のょ うに軟化速度定数を求めた.

$$
\begin{aligned}
& \mathrm{dX}_{\mathrm{d}} / \mathrm{d} \theta=\mathrm{k}_{\mathrm{d}}\left(1-\mathrm{X}_{\mathrm{d}}\right) \\
& \ln \left(1-\mathrm{X}_{\mathrm{d}}\right)=-\mathrm{k}_{\mathrm{d}} \theta
\end{aligned}
$$

ここで, $\theta$ は加熱時間 $(\mathrm{s}), \mathrm{k}_{\mathrm{d}}$ は軟化速度定数 $\left(\mathrm{s}^{-1}\right)$ で ある. 軟化率と加熱時間との関係は, 式 (2) の積分式 (2)-a で表すことができ， $1-\mathrm{X}_{\mathrm{d}}$ の対数と加熱時間との 関係をFig. 2 に示した。 その結果，ほぼ直線が得られ， ダイコンの軟化率と加熱時間との関係は，一次の速度式 で表せるものとした。

\section{2. 加熱によるペクチンの分解}

加熱処理したベクチンの $\boldsymbol{\beta}$-脱離反応をチオバルビ ッール酸反応による吸光度で表し，加熱時間との関係て Fig. 3 に示した. $90^{\circ} \mathrm{C} \sim 110^{\circ} \mathrm{C}$ の温度範囲でペクチン溶 液の加熱処理温度が高くなるほど，急速に $\beta$-脱離反応

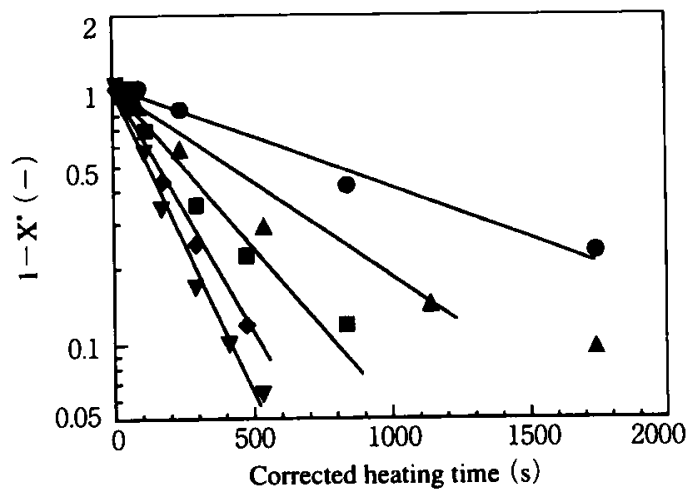

Fig. 2 Softening ratio of Japanese radish at various temperatures

Keys are the same as in Fig. 1. * $\mathrm{X}$ : softening ratio of Japanese radish. 


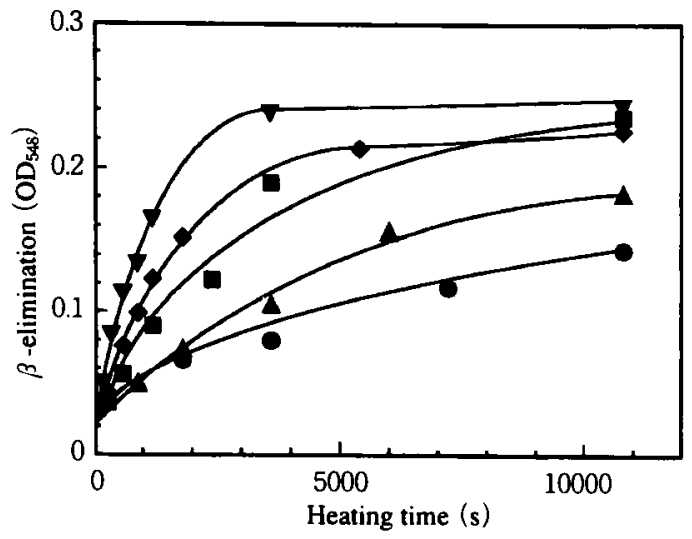

Fig. 3 Changes in $\beta$-elimination reaction $\left(O D_{548}\right)$ for citrus pectin solution heated at various temperatures

Heating temperature $\left({ }^{\circ} \mathrm{C}\right):-9,90 ; \mathbf{\Delta}, 95 ; \square$, $100 ; \bullet, 105 ; \nabla, 110$. The citrus pectin solution: $0.5 \%$ citrus pectin in $1 / 10 \mathrm{M}$ sodium phosphate buffer ( $\mathrm{pH} 6.5)$

が進行した．また，加熱時間が長くなるほど反応が進行 したが, $110^{\circ} \mathrm{C} \cdot 60$ 分以降ではほとんど進行しなくなり， 吸光度は約 0.24 で一定となっていた。

加熱によって起こるペクチンの分解反匛， $\mathrm{pH}$ が中 性付近では主に $\beta$-脱離反応に上る ${ }^{5) \sim 7)}$ と考えられてい る. 本実験においても，加熱中のペクチンの分解は $\beta$ 脱離反応によると考えられることから，次のようにべク チンの分解率を求めた，すなわち，末加熱処理のペクチ ン溶液の吸光度 $\left(\mathrm{OD}_{0}, 0.018 \mathrm{~nm}\right)$ ，加熱処理によって平 衡に達したときのぺクチン溶液の吸光度 $\left(\mathrm{OD}_{\mathrm{e}}\right)$ ，および 加熱処理したペクチン溶液の吸光度 (OD) から式 (3) によってペクチンの分解率 $\left(\mathrm{X}_{\mathrm{p}}\right)$ を求めた。なお， $\mathrm{OD}_{\mathrm{e}}$ は $100^{\circ} \mathrm{C} \sim 110^{\circ} \mathrm{C}$ て 3 時間 8 時間処理した吸光度の平均 值 $(0.238 \mathrm{~nm})$ とした.

$$
\mathrm{X}_{\mathrm{p}}=\left(\mathrm{OD}-\mathrm{OD}_{0}\right) /\left(\mathrm{OD}_{\mathrm{e}}-\mathrm{OD}_{0}\right)
$$

ペクチンの分解率と加熱処理との関係が一次の速度式 に従うとす机ば，式(2) および式(2)-a と同じ形の式を用 いることができる．ただし，この場合はダイコンの軟化 率 $\mathrm{X}_{\mathrm{d}}$ をぺクチンの分解率 $\mathrm{X}_{\mathrm{p}}$ に固き換え，式 (2)の $\mathrm{k}_{\mathrm{d}}$ は ペクチンの分解速度定数 $\mathrm{k}_{\mathrm{p}}\left(\mathrm{s}^{-1}\right)$ となる.

ここで, $1-\mathrm{X}_{\mathrm{p}}$ の対数と加熱時間との関保を Fig. 4 に 示した. その結果, $90^{\circ} \mathrm{C} \sim 110^{\circ} \mathrm{C}$ の温度範囲で直線関係 $(r=-0.997 \sim-0.973)$ が成立していたので, ペクチンの 分解之加熱時間との関係は一次の速度式で近似できるも
のとした.

加熱によるペクチンの $\beta$ - 脱離反応はエステル化度が 大きく影響していると言われている。本実験に用いた相 橎ペクチンのエステル化度を測定したところ，66.9\%で あった，一方，ダイコンに含まれるぺクチンのエステル 化度は, 夏タイコンで $65 \%$, 冬ダイコンで $70 \%$ と報告 ${ }^{33)}$ とされており，本実験で用いた相㗚へクチンの值に近 かったこのことから，本実験で用いた柑橎ぺクチンの 加熱分解とダイコンの組織内で起こっているペクチンの 加熱分解は，共に同程度の $\beta$ - 脱離反応によるものと推 察される，一方，タイコンの加熱による軟化は，ペクチ ンの $\beta$ - 脱離反応に関係している4) と考えられているこ とから、次の項で加熱によるダイコンの軟化速度と相桶 ペクチンの分解速度について, 速度論的な比較を行っ た.

3. ダイコンの軟化速度とペクチンの分解速度の比较

Fig. 2 および Fig. 4 からられれぞれダイコンの軟化速 度定数とぺクチンの分解速度定数を最小二乗法で求め,

Fig. 5 にアレニゥスプロットを行った，なお，Fig. 5 に 示した中間温度 $\left(97.5^{\circ} \mathrm{C}, 102.5^{\circ} \mathrm{C}\right.$ および $\left.107.5^{\circ} \mathrm{C}\right)$ におけ るデータはFig. 2 に示していない。

Fig. 5 に示したように，ダイコンの軟化速度定数およ びペクチンの分解速度定数は，それぞれ $90^{\circ} \mathrm{C} \sim 110^{\circ} \mathrm{C} の$ 温度範囲で高い相関（ $\mathrm{r}=-0.962$ および $\mathrm{r}=-0.998 ） の$ 直線となった．また，ダインの軟化速度は，ペクチン の分解速度よりも約 10 倍大きかったが，両者の傾きは ほとんど一致しており，それぞれの直線から，ダイコン の軟化およびペクチン分解のみかけの活性化エネルギー

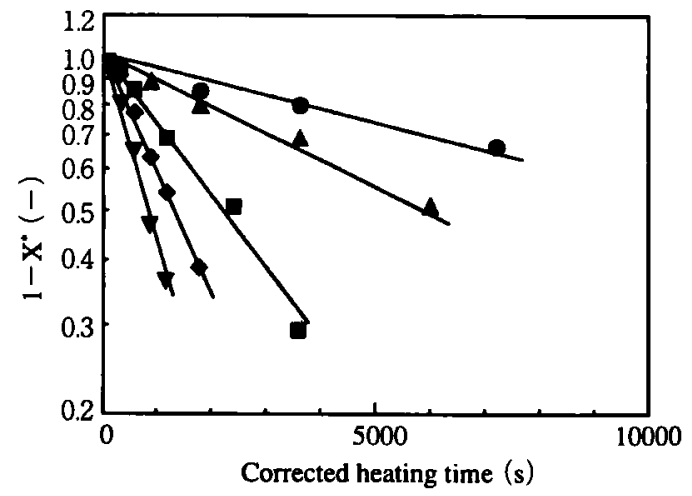

Fig. 4 Degradation ratio curves for citrus pectin heated at various temperatures

Keys are the same as in Fig. 3.' * $\mathrm{X}$ : degradation ratio of pectin. 


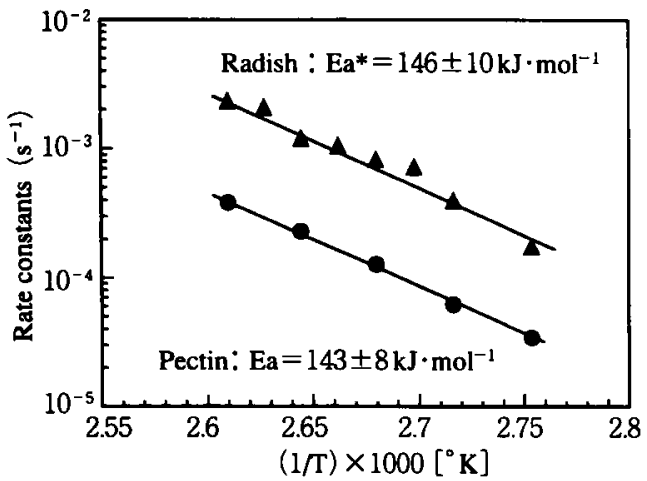

Fig. 5 Arrhenius plots of softening rate constants for Japanese radish $(\boldsymbol{\Delta})$ and $\beta$-elimination rate constants for citrus pectin ( ) by thermal processes

* Ea : Activation energy.

を求めたところ, 次のようになった.

ダインの軟化 : $146 \pm 10 \mathrm{~kJ} \cdot \mathrm{mol}^{-1}$

ペクチンの分解 : $144 \pm 8 \mathrm{~kJ} \cdot \mathrm{mol}^{-1}$

両者の活性化エネルギーは非常に近い值となっていたこ とから，加熱によるダイコンの軟化と $\beta$-脱離によるぺ クチンの分解は，密接な関係のあることが示唆される.

次に，処理温度书よび処理時間が一致するダイコンの 軟化率とペクチンの分解率のデータを Fig. 6 に示した. その結果, ペクチンの分解率がわずか 0.1 であっても夕゙ イコンの軟化率は 0.7 まで進んでいた。このことは，初 期のペクチン分解がダイコン軟化に大きく寄与する可能 性を示唆している．また，ダイコンの軟化率とペクチン 分解率の関係は，処理温度に依存しない，指数関数的な 曲線となった。

荆上 ${ }^{3)}$ は，野菜類の加熱による軟化は主に $\beta$-脱離反 応によるべクチンの分解および低分子化したぺクチンの 溶出によって進行するとしている．前者はペクチンの $\beta$ - 脱離反応が, 後者はペクチンの拡散がダイコン軟化 に寄与していると考えることができる. SATTERFIELD ${ }^{14)}$ は搪散律速で得ら㧈る活性化エネルギーは, 反応律速の 活性化エネルギーの約半分になることを示した。また， 鈴木ら ${ }^{15)}$ はコメのクッキング速度の測定で, $75^{\circ} \mathrm{C}$ $100^{\circ} \mathrm{C}$ ではクッキングによる活性化エネルギーは $79 \mathrm{~kJ}$. $\mathrm{mol}^{-1}$ となるが， $110^{\circ} \mathrm{C} \sim 150^{\circ} \mathrm{C}$ の高温では約半分の 37 $\mathrm{kJ} \cdot \mathrm{mol}^{-1}$ となったことに関して, $100^{\circ} \mathrm{C}$ 以下では水と コメ成分との反応律速で， $110^{\circ} \mathrm{C}$ 以上では水の掂散律速 でクッキングが進行しているためであると考察してい

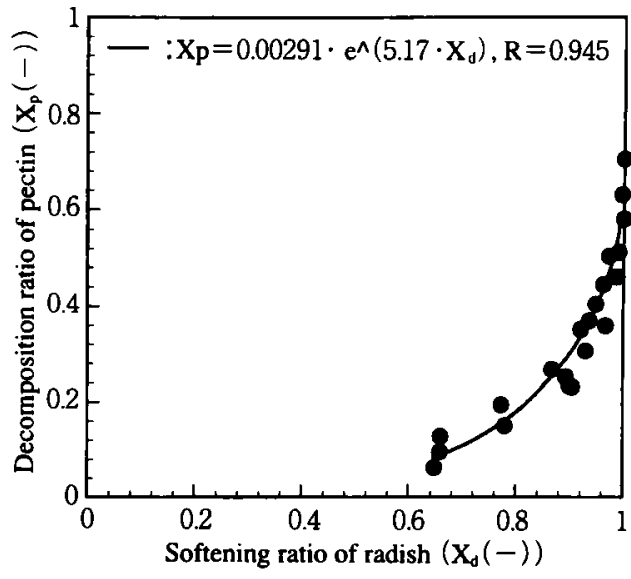

Fig. 6 Relationship between softening ratios of Japanese radish and decomposition ratios of citrus pectin by heating in the temperatures ranging from $90^{\circ} \mathrm{C}$ to $110^{\circ} \mathrm{C}$

る. 本実験においてダイコン軟化の活性化ェネルギーと ペクチン分解の活性化ェネルギーがほとんど等しい值で あったことは，ダイコン軟化は反応律速で進行している ことを示唆しており，ダイコンの軟化は第一義的にペク チンの分解によって起こる可能性が高い.

さらに，ダイコンの軟化速度はペクチンの分解速度よ りも約 10 倍大きく，しかも初期のペクチン分解がダイ コンの軟化に寄与している可能性が示唆されたことから (Fig. 6)，わずかなぺクチン分解であってもダイコンの 軟化が進行していると考えられる。

香西 ${ }^{2)}$ らは加熱によるダイコンの軟化速度定数を $80^{\circ} \mathrm{C} \sim 99.5^{\circ} \mathrm{C}$ の温度範囲で測定し，新鮮なダイコンの活 性化エネルギー $\left(111 \mathrm{~kJ} \cdot \mathrm{mol}^{-1} \sim 139 \mathrm{~kJ} \cdot \mathrm{mol}^{-1}\right)$ を求め た。この値は，本実験で得られた値よりも若干小さかっ た. 本実験で得た值が大きい理由は, タイコンの種類や 産地等の影響および加熱処理の温度範囲が異なることも 考えられるが，修正加熱時間を導入して測定結果を解析 したことも一因になっていると考えられる(2).

要約

タイコンの加熱による軟化速度と柑檑ペクチンの加熱 による分解速度を $90^{\circ} \mathrm{C} \sim 110^{\circ} \mathrm{C}$ の温度範用で測定し，両 者の関係を速度論的に比較した。

（1）加熱によるダイコンの軟化は， $90^{\circ} \mathrm{C} \sim 110^{\circ} \mathrm{C}$ の温 度範囲で一次の速度式に近似した。

（2）加熱に上る柑檑ペクチンの分解は， $90^{\circ} \mathrm{C} \sim 110^{\circ} \mathrm{C}$ 
の温度範囲で一次の速度式に近似した.

(3) 加熱によるダイコンの軟化速度と柑橎ペクチンの 分解速度は, $90^{\circ} \mathrm{C} \sim 110^{\circ} \mathrm{C}$ の温度範囲でアレニウス式に 従い，みかけの活性化エネルギーは，それぞれ $146 \mathrm{~kJ}$. $\mathrm{mol}^{-1}$ と $144 \mathrm{~kJ} \cdot \mathrm{mol}^{-1}$ でほとんよ゙等しかった. このこ とから,ダィコンの軟化はペクチンの分解によって支配 されている可能性が高い.

\section{文献}

1）松浦容子・香西みどり・㚼江敬子・島田淳子：日 食工誌，36，97 (1989).

2）香西みどり・中川弥子・谷澤容子・畑江敬子・島 田㳯子：日食工誌，39，41（1992）。

3）㴥上倫子: 栄食誌，36，219 (1983).

4) 㴊上倫子: 家政誌, 37, 1029 (1986).

5) Albersheim, P., Neukom, H. and Deuel, H. : Arch. Biol. Biophys., 90, 46 (1960).

6）判上倫子: 栄食誌, 36, 294（1983）.

7）澤山 茂·川端晶子：采食誌，42，461（1989）.
8）福井作蔵 : 還元糖の定量法（学会出版センター, 東京), p. 62 (1990).

9）塩田芳之 - 根岸智史 - 畑中干歳 : 日食工誌, 33, 399 (1986).

10）岡崎 尚・鈴木䙾一・前重靜彦・久保田清 : 日食 工誌, 38, 784 (1991).

11）岡本賢一・畑中千歳 - 小沢潤二郎：農学研究, 50, 61 (1964).

12）岡崎 尚·鈴木寛一・前重靜彦・久保田清: 日食 工誌，39，295 (1992).

13）㴊上倫子 : 家政誌, 38, 465 (1987)。

14) Satterfield, C. N. : Masstransfer in Heterogenous Catalysis, (MIT Press) p.1929 (1970).

15) Suzukı, K., Kuвota, K., Омichi, M. and Hosaka, H. : J. Food Sci., 41, 1180 (1976).

16) Kasai, M., Hatae, K., Shimada, A. and Iibuchi, S. : Nippon Shokuhin Kogyo Gakkaishi, 41, 933 (1994).

（平成 9 年 4 月 14 日受付, 平成 9 年 6 月 11 日受理) 